\title{
The Role of Employee's Social Capital in the Relationship between Empowerment and Cynicism
}

\author{
Çalışanların Sosyal Sermayesinin Güçlendirme ve Sinizm İlişkisindeki Rolü
}

Anıl BOZ SEMERCi ${ }^{1}$

\begin{abstract}
This paper aims to explain the relationship between organizational cynicism, empowerment and the individual's sense of social capital in terms of gender. In this direction the obtained data were analyzed by structural equation model. The results indicate that structural and psychological empowerments have reducing effect on organizational cynicism, and social capital has a moderator role between psychological empowerment and organizational cynicism for both women and men. However women with high social capital have a greater reduction of psychological empowerment on organizational cynicism than men with high social capital. These findings offer few recommendations for managers and employees. Managers to decrease employees' negative attitudes and to ease cynicism may use empowerment. However, even employees perceive as psychologically empowered, managers also should consider some other individual sources such as social capital that can buffer or strengthen the cynicism. Particularly for women employees, managers can focus more on psychological and social resources in order to decrease negative work consequences. Such an investigation is necessary to reveal the predictors of cynicism as one of the important concept in organizational behavior and management literature. It is also valuable to understand the differences between individuals in terms of cynical behaviours towards their organizations.
\end{abstract}

Keywords: Organizational cynicism, structural empowerment, psychological empowerment, social capital, gender

\section{INTRODUCTION}

Since 1990s, there has been a growing interest on the presence of cynical workers in the workplace. Although https://orcid.org/0000-0002-9690-8122

\begin{abstract}
ÖZET
Bu çalışma örgütsel sinizm ve güçlendirme arasındaki ilişkiyi sosyal sermaye ve cinsiyet ile açıklamayı amaçlamıştır. Bu doğrultuda toplanan veriler yapısal eşitlik modeli ile analiz edilmiştir. Sonuçlar çalışanların yapısal ve psikolojik güçlendirme algılarının örgütsel sinizm üzerinde azaltıcı etkisini ve sosyal sermayenin hem kadın çalışanlar hem de erkek çalışanlar için psikolojik güçlendirme ve sinizm arasındaki düzenleyici rolünü ortaya koymuştur. Bu bulgular hem yöneticiler hem de çalışanlar için birtakım öneriler sunmaktadır. Çalışanlarının olumsuz tutumlarını ve sinizmi azaltmak isteyen yöneticiler güçlendirmeyi bir araç olarak kullanabilirler. Ancak çalışanlar psikolojik olarak kendilerini güçlendirilmiş algılasalar dahi, yöneticiler sinizmi güçlendirecek veya zayıflatacak diğer kişisel faktörleri, sosyal sermaye gibi, dikkate almalıdırlar. Özellikle kadın çalışanlar için yöneticiler psikolojik ve sosyal faktörlere daha çok odaklanabilirler. Bu tür bir araştırma örgütsel davranış ve yönetim literatüründe önemli bir kavram olan sinizmin öncüllerini açıklamak için gereklidir. Ayrıca bu çalışma neden bazı insanların örgütlerine karşı diğerlerine göre çok daha fazla sinik davranış gösterdiklerini anlamak açısından da önemlidir.
\end{abstract}

Anahtar kelimeler: Örgütsel sinizm, yapısal güçlendirme, psikolojik güçlendirme, sosyal sermaye, cinsiyet 
ased in today's workplaces (Kanter and Mirvis, 1989; Reichers, Wanous and Austin, 1997; Feldman, 2000). Many studies have suggested that cynical employees have low job satisfaction, organizational commitment, performance, productivity and high intention to quit, which are all considered as negative consequences for the organizations (Brown and Cregan, 2008). Moreover, not only for organizations but also for employees cynicism is associated with negative emotions, stress and cardiovascular diseases (Greenglass and Julkunen, 1989; Johnson and O'Leary-Kelly, 2003).

In Oxford English Dictionary cynical person is defined as 'one who shows a disposition to disbelieve in the sincerity or goodness of human motives and actions.' Kanter and Mirvis (1989) described cynics as 'close-minded and disillusioned.' Anderson (1996) characterized cynicism as the specific attitude that consists frustration, hopelessness, disillusionment and distrust. Although there were some discussions on consideration of cynicism as a personality trait (Kanter and Mirvis, 1989; Pope et al., 1993), there is a consensus that cynicism is a negative attitude that can be examined both as general and toward a specific object (Andersson and Bateman, 1997; Wanous et al., 2000). The literature on cynicism that has specific objects contains studies on work, organizations, industries or leaders. The present research focuses on a specific form of cynicism within an organizational context. Organizational cynicism is defined as individuals' negative attitudes toward their organization (Dean et al., 1998). It is important to note that it is considering as a state - not a trait - shaped by employees' organizational experiences and can be changed over time (Dean et al., 1998).

In their study on conceptualization of organizational cynicism Dean, Brandes and Dharwadkar, (1998) have revealed that organizational cynicism is associated with variety range of organizational experiences and it should include other forms of organizational factors. Similarly, Wilkerson (2002) has extended the framework of organizational cynicism by adding other organizational objects like procedures, processes, and management. Chiaburu et al., (2013) in their meta-analytical research, have also categorized other organizational factors as positive and negative work experiences and considered them as antecedents of organizational cynicism. The perceived organizational support (Byrne and Hochwarter, 2008), justice (Bernerth et al., 2007; Fitzgerald, 2002), leadership behaviours (Bommer et al., 2005; Polatcan and Titrek, 2013), coworkers' influence (Wilkerson et al., 2008), management politics (Davis and
Gardner, 2004) and breach of psychological contract (Bashir et al., 2011) are some searched variables in employees' work experience - cynicism linkage. Although the researches on employees' work experiences and cynicism have been varied in recent years, they are still sparse. It is clear that consideration of different experiences and perceptions of employees with cynical behaviours in the workplace would be beneficial to make more comprehensive assessment. Employee empowerment is one of the managerial approaches that help employees to motivate and perform better.

The objectives of current study are to investigate the relationship between empowerment and cynicism and examine whether structural and psychological empowerment can differentially predict the organizational cynicism or not. Further, it is aimed to examine the role of social capital in empowerment and cynicism relationship. Such an investigation is necessary to reveal the predictors of cynicism and examine possible reasons behind why some people are so much more cynical about their organizations than others. It is also valuable to understand to how supportive sources of employees, such as personal social capital, interact with perception of empowerment and affect cynicism. Such knowledge can provide wider perspective and help researchers to the consideration of different organizational and individual sources in examination of organizational cynicism of employees.

\section{THEORETICAL BACKGROUND and HYPOTHESES}

\section{Empowerment and Organizational Cynicism}

Since employees' experiences play a central role in organizational cynicism, managerial approaches that result in positive perceptions of employees help to impede cynicism. Today's intensively competitive working conditions require empowered employees. Kanter's theory of structural power in organizations (1979) posits that providing employees with access to resources and opportunities help them to do their job more effectively and efficiently. Employees who have structural power can act quickly and take innovative decisions. They can access resources and opportunities, which provide convenient conditions to improve professionally (Gilbert et al.., 2010). Moreover, sharing power and authority with employees create participative work climate and increase each employees' control and responsibilities (İş̧̧i et al., 2013). 
Research evidence shows that structural empowerment is related to a variety of positive organizational and job-related outcomes such as increased organizational citizenship behaviours, commitment, satisfaction, job involvement, energy and decreased burnout and job tension. In line with these findings, it is proposed that as employees are empowered, they are more likely to have increased intrinsic motivation, which in turn will positively affect their positive workplace behaviours. Therefore, their willingness to engage in negative attitudes like cynicism will decrease.

$H_{1}$ : Structural empowerment negatively effects employees' organizational cynicism.

Empowerment has been explained with its two dimensions, which are the structural, explained above, and psychological empowerment. While structural empowerment is associated with organizational perspective and managerial practices, psychological empowerment is an individual and psychological state. It is an intrapersonal sense of empowerment, which occurs as a result of cognitive processes within the individual (Zimmerman, 1995). Thomas and Velthouse (1990) described four components of psychological empowerment: meaning, competence, self-determination, and impact. According to Spreitzer (1995), competence is defined as an individual's feeling that they have the ability to perform their work well. Meaning is identified as the "degree to which people care about their work". Self-determination refers to "feelings of control over one's work" (Bandura, 1986). Impact defines as the extent to which an individual believes his/her work makes a difference in achieving the purpose of the task and he or she can influence organization (Spreitzer, 1995). Accordingly, employees shape their perceptions based on their interpretation of the organizational climate. That is, individuals may feel a sense of psychological empowerment as a result of environmental factors such as positive work environment structures, which is related to structural empowerment.

Numerous studies revealed that employees' perceptions on structural empowerment resulted in higher psychological empowerment (Conger and Kanungo, 1988; Laschinger et al., 2001; Spreitzer, 1995). It is proposed and verified that when individuals view their work environment as providing support, resources and opportunities, they feel psychologically empowered.

$\mathrm{H}_{2}$ : Structural empowerment positively effects employees' psychological empowerment.
Psychological empowerment was also associated with positive work outcomes. According to Spreitzer, psychologically empowered employees believe that their work has an important impact on others and their contributions are taken seriously. They see themselves as capable to affect their workplace and job. Thomas and Velthouse (1990) reported that empowered employees show more concentration, initiative, and resiliency. Therefore, these employees are expected to have less negative work behaviours and experience more positive work outcomes. For example, many researchers argued and verified on that empowered employees are more likely to be more committed to their organization (Avolio et al., 2004; Bhatnagar, 2007). Derived from these explanations, it is expected that psychologically empowered employees will have less cynicism toward their organizations.

$H_{3}$ : Psychological empowerment negatively effects employees' organizational cynicism.

\section{Moderating Role of Social Capital}

The second theoretical basis of this study is conservation of resource theory which is developed by Hobfoll (1989). Theory suggests that people try to protect their resources, and have new ones. If these resources are lost or threatened, individuals feel stress. These resources are categorized as objects (car, house), conditions (e.g. marriage, job security), energies (money, time) and personal characteristics (e.g. psychological or social capital). Social capital is one of the supportive personal resources that individuals can have. Bourdieu (1980) defined social capital as'the sum of resources, actual and virtual, that accrue to an individual or a group by virtue of possessing a durable network or less institutionalized relationships of mutual acquaintance and recognition'. Social capital is a relational concept and fosters collaboration between individuals. It helps to access to resources, support and provides alternative uses of time. According to conservation of resource theory individuals who have rich supportive resources likely to be less negatively affected by the resource drain or loss.

Many studies have examined relationships between social capital and positive health outcomes. Previous studies have found that social capital is related to higher levels of general health and subjective well-being (Groot et al. 2007; Subramanian et al., 2002). Although there are limited studies on social capital in organizational context, it is also suggested that social capital represent as an important source for sustainable organizational advantage (Nahapiet and Ghoshal, 1998; Leana and 
Van Buren, 1999). Bolino et al., (2002) have indicated in their conceptual study that social capital enhances employees' organizational citizenship behaviours, which is a positive attitude.

Accordingly, individuals with high social capital will likely to have trust, liking, and identification in their professional lives. When employees participate in social life, have tolerance for diversity and feel trust to other people, they will be less likely to experience negative attitudes toward specific objects in their both private and professional life domains. In another words, beside the buffering role of social resources in diminishing negative effects, they may also enhance the positive impacts on outcome variables.

Consistent with this notion, social capital may interact with perceptions of empowerment in determining organizational cynicism. That is, employees with high social capital may be less likely to experience cynicism that also negatively affected by empowerment. The proposed research model can be seen in Figure 1.

$\mathrm{H}_{4}:$ Employees'social capital moderates the relationship between structural empowerment and organizational cynicism such that the negative effect of structural empowerment on employees' organizational cynicism will be stronger when employees have high social capital.

$H_{46}$ : Employees' social capital moderates the relationship between psychological empowerment and organizational cynicism such that the negative effect of psychological empowerment on employees' organizational cynicism will be stronger when employees have high social capital.

\section{Role of Gender}

The presence and content of social capital vary according to gender. When women's networking activities in organizations were examined, it was found that they showed less socializing behavior compared to men (Forret and Dougherty, 2001). Women face inequalities and difficulties on accessing resources in organizations (O'Neill and Gidengil, 2013; Wellington and Spence, 2001). Social network is one of the fundamental factors that women can benefit from in order to cope with obstacles in workplaces. However, the social network structures indicate some differences across women and men. The social network of each person refers his or her ties with other people and the resources that he or she attained. Greve and Salaff (2003), in their search on entrepreneurs, have stated that women prefer to create and maintain their social networks within close environment (such as family members or relatives) compared to men. This was interpreted as a result of inequalities that women face in male-dominated workplaces. Similarly, in the study conducted by Orhan (2001) it is reported that while men use professional resources as a first application resource, women consult to their spouses and families.

Across organizations and sectors women may be discriminate from men within the context of their job and professional positions in the organizations. These arguments may be explained with 'old boys' networks' perspective (McDonald, 2011). It suggests that women and minorities can access to the limited networks that are dominated by female and minorities. Consistently, the 'Similarity-Attraction' paradigm also supports this approach. This paradigm explains the influence of sex similarity on individuals' judgements. Accordingly, 'individuals'sex leads the perceived similarity in attitudes and values which in turn leads to interpersonal attraction.' (Graves and Powell, 1995, p. 86) Applying the paradigm to the network context, men may prefer to establish networks with other men, which causes the exclusion of women from these networks. Taking into consideration of both 'old boys' network' and 'similarity-attraction' paradigms, it could therefore explain the inequalities and gender differences in networking context.

Researchers also argue that women and men differ not only in establishing networks but also in support types that they needed. Bem (1974) stated that while the masculine role consists more instrumental qualities, the feminine role endorses more communal and socio-emotional traits. This notion indicates consistency with socialization process and social role expectancy theory. According to social role theory, behavioral differences of women and men originate from gender-specific socialization processes (Eagly, 1987). Women are considered to value on interpersonal relationships, be more sensitive and display communal (nurturing, interpersonally sensitive) behaviors. On the other hand, men are expected to display independent and assertive behaviors. These expectations and stereotypes lead women's networks that are likely to involve more socio-emotional contacts, whereas instrumental ties and task-oriented resources arise in networks of men (Emmerik, 2006).

In line with these considerations, it is proposed that the perception of social capital may affect women and men differently. That is, it may interact with empowerment differently and therefore, the effect on 
organizational cynicism may vary across women and men employees.

$H_{5}$ :The moderating role of social capital in relationship between empowerment and organizational cynicism is significantly different across female and male employees.

ved structural and psychological empowerment, social capital and organizational cynicism. Structural and psychological empowerment was measured by Laschinger et al. (2001) and Spreitzer (1995), respectively, and Turkish adaptation of scales was made by Surgevil et al. (2013). Structural empowerment scale consists of 18 items and 6 sub-dimensions including opportunity, information, support, resources, formal and informal power. Psychological empowerment scale consists of 12 items in total and 4 factors including meaning, competence, self-determination and impact.

The second section of the questionnaire consists social capital scale with 28 items, 9 factors developed by Onxy and Bullen (2000). Turkish validation and reliability tests were done

Figure 1: The Proposed Research Model

Note:SC-F1:Participation in local community, SC-F2:Neighborhood, SC-F3: Sense of belonging, SC-F4: Tolerance for diversity, SC-F5: Participation of non-governmental organizations, SC-F6: Trust to people, SC-F7: Trust to environment, SC-F8: Proactivity in a social context, SC-F9: Social agency

\section{METHODOLOGY}

\section{Sample}

Participants were employees of different production and service branches in Turkey such as bank, insurance, consulting, tourism, transportation, agriculture and catering. The sample consisted of 332 employees randomly recruited from public and private companies in Turkey. Of the 675 distributed questionnaires, 342 were returned with a response rate of $50.6 \%$. The data obtained from 10 employees were not included in to the analysis because of the $40 \%$ and above missing values on the items. Finally, the usable responses were obtained from 332 employees. The mean age of the participants was 40.9 and of these $48.1 \%$ was female and $51.9 \%$ was male. The sufficiency of sample size is measured by Kaiser-Meyer-Olkin (KMO) test which are above 0.5 (Field, 2013) for structural empowerment (0.58) psychological empowerment (0.59), social capital (0.62) and organizational cynicism scales (0.68).

\section{Measurement}

The self-reported questionnaire contains four main sections designed to measure demographics, percei- by Ardahan (2012). The factors of the scale are; participation in local community, neighborhood, sense of belonging, tolerance for diversity, participation of non-governmental organizations, trust to people, trust to environment, proactivity in a social context and social agency. Although the original form of scale consists items in question form, they transformed into expressions which the participant can report the degree of participation. It also helps to obtain integrity and consistency with the form of other scales in the questionnaire used in this study.

Organizational cynicism, which is the last part in our questionnaire, has been measured by organizational cynicism scale developed by Brandes et al., (1999) and adapted to Turkish by Kalağan (2009) and Karacaoğlu and Ince (2012). The scale consists of 13 factors and 3 factors as cognitive, emotional and behavioral. All these scales used were measured with a 5-point Likert-type ( 1 = Strongly Disagree, 2 = Disagree, 3 = Undecided, 4 $=$ Agree and $5=$ Strongly Agree). The last part of the questionnaire ends with the demographics as gender and age.

\section{Analytical Procedure}

Hypothesis testing consists two main steps. First, the influences of structural and psychological empowerment on organizational cynicism and moderation impact of social capital have been tested. Later, it was examined whether these relationships between 
variables varied between male and female workers. Multi-group structural equation modeling was applied in the study. Therefore, before going to the hypothesis tests, factor structures of the research model were examined within groups, followed by model predictions and model modifications. After the measurement equivalence was established, the inter-variable relations were evaluated between the whole data set and the female and male groups. All these analysis were analyzed with the AMOS.23 statistical program.

\section{RESULTS}

As assumed in the hypotheses, in addition to variables relations, it is also stated that these relationship might be different between male and female employees. Hence, multi-group structural analyses that consists measurement and structural models were carried out.

\section{Measurement Invariance Analysis}

In multi-group confirmatory factor analysis, an unconstrained model is established that primarily assumes formal equivalence of variables and related items without any restrictions on factor loadings or intercorrelations. Afterwards, the models were obtained with restrictions factor loadings (metric invariance), factor loads + factor correlations (scale invariance), fac- tor loads + correlations + error terms (rigid invariance) respectively and compared within male and female groups. In this comparison, it is taken into account whether the $x^{2}$ differences are significant, as well as the model fitting indices. The obtained findings are presented in Table I.

Although, the researchers try to have strict invariance between groups, it is generally difficult to obtain. Therefore, the metric or scalar invariance are considered sufficient to achieve measurement invariance within groups (Anderson and Gerbing, 1988).

The obtained findings indicated that factorial structure is equivalent across male and female employees. In other words, the results revealed that measurement model is mathematically equal between the groups. Metric invariance $\left(\Delta x^{2}(d f=26)=23.3, p=0.16\right.$; $\Delta \mathrm{CFI}=0.000 ; \Delta \mathrm{IFI}=0.000 ; \Delta \mathrm{GFI}=0.002 ; \Delta \mathrm{SRMR}=0.001 ;$ $\triangle \mathrm{RMSEA}=0.001)$ and scalar invariance $\left(\Delta \mathrm{X}^{2}(\mathrm{df}=22)=29\right.$, $\mathrm{p}=0.22 ; \Delta \mathrm{CFI}=0.000 ; \Delta \mathrm{IFI}=0.01 ; \Delta \mathrm{GFI}=0.001 ; \Delta \mathrm{SR}-$ $M R=0.001 ; \triangle R M S E A=0.001$ ) did not indicate significant $\mathrm{X}^{2}$ differences. This demonstrates that the participants interpret and understand the measured items in the same way. It was also found that all factors were loaded at higher rates than 0.5 and under their related factors, which lends support for construct validity (Anderson and Gerbing, 1988).

Table 1: Findings on Multi-Group Confirmatory Factor Analysis

\begin{tabular}{lcccccc}
\hline Modeller & CFI & IFI & GFI & SRMR & RMSEA & $\Delta X^{2}$ \\
\hline $\begin{array}{l}\text { Model 1: } \\
\text { Unconstrained model }\end{array}$ & .94 & .93 & .95 & .04 & .032 & \\
\hline $\begin{array}{l}\text { Model 2: } \\
\text { Metric invariance }\end{array}$ & .94 & .93 & .95 & .04 & .032 & 23.3 \\
\hline $\begin{array}{l}\text { Model 3: } \\
\text { Scalar invariance }\end{array}$ & .94 & .92 & .95 & .04 & .033 & 29 \\
\hline $\begin{array}{l}\text { Model 4: } \\
\text { Strict invariance }\end{array}$ & .93 & .92 & .95 & .04 & .034 & $31.1^{*}$ \\
\hline
\end{tabular}

Note: $\mathrm{X}^{2}=$ Ki Kare; GFI = Goodness of fit index; IFI = Incremental fit index; CFI = Comparative fit index; SRMR = Standardized root-meansquare residual; RMSEA $=$ Root-mean-square error of approximation. ${ }^{*} p<.05,{ }^{* *} p<.01$

Table 2: Findings on Descriptive Statistics, Correlations and Reliabilities

\begin{tabular}{|c|c|c|c|c|c|c|c|}
\hline Variables & 1 & 2 & 3 & 4 & Mean & SD & Cronbach's a \\
\hline 1. Structural empowerment & 1 & & & & 4.34 & 1.02 & .82 \\
\hline 2. Psychological empowerment & $.067^{* *}$ & 1 & & & 4.43 & 1.10 & .71 \\
\hline 3. Social capital & $.042^{* *}$ & $.055^{*}$ & 1 & & 3.57 & 1.04 & .75 \\
\hline 4. Organizational cynicism & $-.051^{* *}$ & $-.59^{* *}$ & $-.42^{* *}$ & 1 & 3.39 & 1.13 & .77 \\
\hline
\end{tabular}




\section{Structural Model Analysis}

After measurement analysis, the structural model was established with observed variables in order to test inter-variable relationships. Structural model was developed in two phases. First, the structural models related to the hypotheses that assume empowerment and cynicism relationships and moderating role of social capital were analyzed for all employees. The results were presented in Table III. The findings indicated that both structural $(\beta=-.38, p<.01)$ and psychological empowerment $(\beta=-.44, p<.01)$ have decreasing effect on organizational cynicism, which were assumed in $\mathrm{H}_{1}$ and $\mathrm{H}_{2}$. When we look at the direct effect of social capital on organizational cynicism, similar to the empowerment variables, it is found that social capital has reducing effect $(\beta=-.27, p<.05)$ on organizational cynicism. For the third hypotheses $\left(\mathrm{H}_{3 \mathrm{a}}\right.$ and $\left.\mathrm{H}_{3 \mathrm{~b}}\right)$, moderator role of social capital between psychological empowerment and organizational cynicism was obtained $(\beta=-13, p<$ .01 ) but no significant moderating role of social capital between structural empowerment and cynicism was obtained $(\beta=.09, p>.05)$.

In the second step in structural analysis, a multi-group comparison within different structural models was conducted to determine whether alternative structural models were equivalent for male and female groups or not. Similar to measurement models analysis, the unconstrained and constrained models were used. The unconstrained model was set without any restriction whereas the constrained model was set to have equal path coefficient across male and female employees' model. Therefore, according to assumed relationships between variables four alternative models were developed and can be summarized as follows: Model 1 demonstrated only the effects of structural and psychological empowerments on cynicism; Model 2 had the effects of structural and psychological empowerments on cynicism and moderating role of social capital between structural empowerment and cynicism; Model 3 contained the effects of structural and psychological empowerments on cynicism and moderating role of social capital between psychological empowerment and cynicism; and lastly Model 4 demonstrated the effects of structural and psychological empowerments on cynicism and moderating effects of social capital between both structural empowerment - cynicism and psychological empowerment - cynicism relationships.

Table 3: Findings on Structural Model with All Data Set

\begin{tabular}{lcc}
\hline Variables & \multicolumn{1}{c}{ All data set } & $\mathrm{R}^{2}$ \\
\cline { 2 - 3 } & $\beta$ & 0.15 \\
Structural empowerment & $-0.38^{* *}$ & \\
Psychological empowerment & $-0.44^{* *}$ & \\
Social capital & $-0.27^{*}$ & \\
Structural empowerment x Social capital & 0.09 & \\
Psychological empowerment x Social capital & $-0.13^{* *}$ & \\
\hline
\end{tabular}

${ }^{*} p<.05,{ }^{* *} p<.01$

Table 4: Findings on Comparison of Structural Models Between Male and Female Groups

\begin{tabular}{|c|c|c|c|c|c|c|}
\hline & CFI & IFI & GFI & SRMR & RMSEA & $\Delta X^{2}$ \\
\hline \multicolumn{7}{|l|}{ Model 1: } \\
\hline Unconstrained Model & .950 & .949 & .950 & .049 & .028 & \\
\hline Constrained Model & .950 & .949 & .950 & .049 & .028 & 9.13 \\
\hline \multicolumn{7}{|l|}{ Model 2: } \\
\hline Unconstrained Model & .951 & .951 & .954 & .045 & .027 & \\
\hline Constrained Model & .951 & .951 & .954 & .045 & .027 & 10.22 \\
\hline \multicolumn{7}{|l|}{ Model 3: } \\
\hline Unconstrained Model & .954 & .954 & .954 & .045 & .026 & \\
\hline Constrained Model & .954 & .954 & .954 & .045 & .026 & $12.07^{*}$ \\
\hline \multicolumn{7}{|l|}{ Model 4: } \\
\hline Unconstrained Model & .950 & .949 & .950 & .048 & .028 & \\
\hline Constrained Model & .950 & .949 & .950 & .048 & .028 & $18.55^{*}$ \\
\hline
\end{tabular}


The findings (Table IV) indicated that for model 3 and 4 the significant $x^{2}$ differences between male and female groups were obtained. Model 3 was a model in which the moderating role of social capital between psychological empowerment and organizational cynicism was put forward. In other words, there was a significant difference in the path coefficients of'psychological empowerment $x$ social capital'variable for male and female employees. Although for both male and female groups structural empowerment, psychological empowerment and 'psychological empowerment $x$ social capital' variables were found as have significant and negative impacts on cynicism, it was seen that the moderating effect of social capital was different in terms of female $(\beta=-.27, p<.01)$ and men $(\beta=-18, p$ $<.05)$ and this difference was significant $\left(\Delta x^{2}=12.07\right.$, $p=0.02$ ). The results also indicated that the reason behind the significant $x^{2}$ difference in model 4 was this significant path coefficient difference of 'psychological empowerment $x$ social capital'.

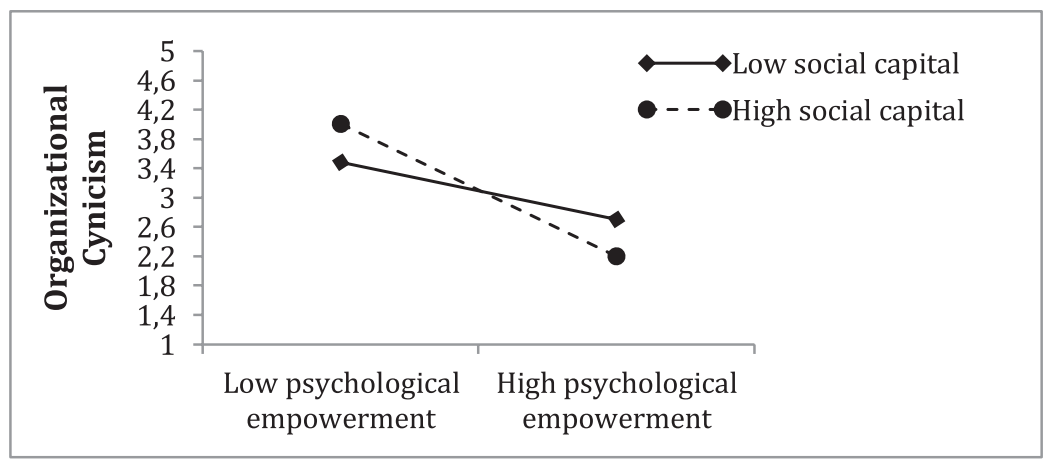

Figure 2: Female Employees

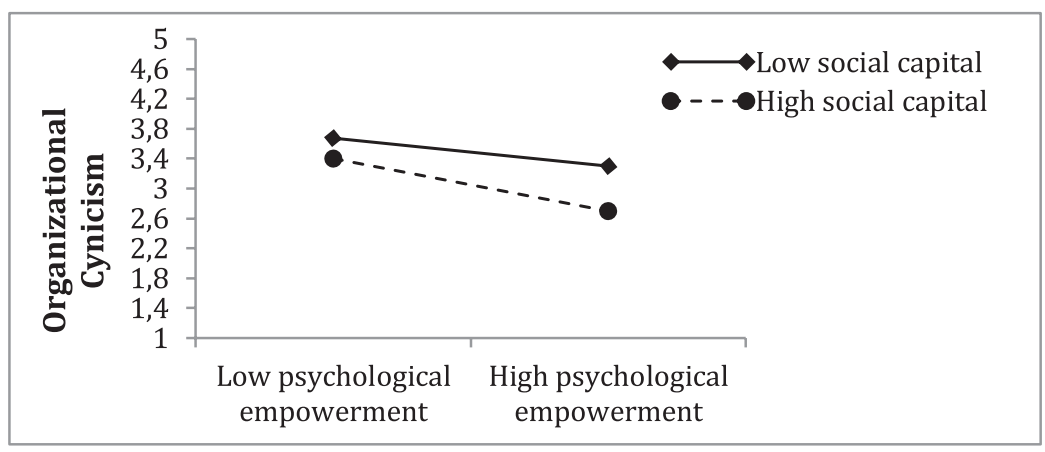

Figure 3: Male Employees

Moderator role of social capital between psychological empowerment and organizational cynicism in terms of male and female employees is shown in Figure 2 and 3 . Accordingly, reducing effect of psychological empowerment on organizational cynicism is higher for employees with high social capital compared to ones with low social capital. In addition, this reducing effect is higher in women with high social capital than men with high social capital.

\section{DISCUSSION}

The results of this study can be interpreted in terms of the each variable in the model and gender. The findings on structural empowerment and organizational cynicism, which is proposed in $\mathrm{H}_{1}$, revealed that structural empowerment negatively effects organizational cynicism. Similarly, the second set of finding is also revealed that psychological empowerment effects organizational cynicism negatively (as proposed in $\mathrm{H}_{3}$ ). This negative effect is verified and no significant difference was found across women and men employees. As suggested in Kanter's theory, employees who have positive organizational implications serve for their benefits and perceive organizational climate as positive, in turn they experience less cynicism to their organizations. Since organizational cynicism is related to employees experiences, regardless of gender, structurally and psychologically empowered employees collect positive experiences and it decreases negative attitudes.

The other finding revealed that, as proposed in $\mathrm{H}_{2^{\prime}}$ structural empowerment positively effects psychological empowerment. That is, structurally empowered employees are more likely to feel motivated and feel empowered. Empowering structures, policies, and practices result in individuals> positive psychological reactions to these activities. Its theoretical and managerial implications are discussed in next sections.

The final finding is the moderation role of social capital between types of empowerment and organizational cynicism. In the light of conservation of resource theory, the significant moderation effect of social capital reveals that the effectiveness of structural and psychological empowerments may be dependent upon the broader personal context. Regardless of gender, at high levels of social capital, psychological empowerment was associated with decreased cynicism. However, this reducing effect 
differed according to gender. When women have high social capital, their perceptions on organizational cynicism is decreasing more than men, by perception of psychological empowerment. These findings suggesting that all employees reciprocate the benefit of psychological empowerment when they have higher social networks. However, its benefits are seen more on women in cynicism context.

\section{CONCLUSION}

The findings of the current study would take interest of not only researchers, but also of employees, managers and policy makers.

\section{Contributions to Literature}

This research complements and expands organizational cynicism literature by applying empowerment and conservation of resource theories. Although Lorinkova and Perry's (2017) study was on empowerment and cynicism, they suggested further research in different organizational settings with varied demographic backgrounds. Chiaburu et al., (2013) also suggested that conservation of resource theory can be used to comprehensively examine cynicism. The traditional focus on work experiences (such as support, justice, leadership behaviours) fails to recognize the employees' strengths or weaknesses and specifically their roles in cynical behaviours. This study provides empirical evidence of the importance social capital for both men and women employees.

Cynicism has often been perceived as employees' negative attitudes that can be manage by organizational activities. However, consideration of employees' demographics reveals better understanding. The diversity in workforce and changing work-life expectations have particularly triggered managers' motivation to explore and implement numerous work practices. Although it is stated that organizations should be moving toward empowerment for all employees, its interactions may be different across women and men employees. As explained in social role theory, women and men differ in support types that they needed and their outcomes. Keeping socialization process in mind, for women, psychological variables may have a much stronger motivation than do other organizational variables.

Social capital is related to sharing and resilience toward additional demands of work. It offers trust, friendship, and participation to social activities. It also help individuals to share their feelings and experiences that are useful to coping and adapting to job demands. However, social capital was not found as moderator between structural empowerment and cynicism. One reason for this absence of effect could be that structural practices that allow employees to access resources, support and opportunities are considering positively, regardless of whether employees' psychological involvement. On the other hand, it is normal to expect that psychological empowerment as a psychological process has an interaction with another psychological construct.

Lastly, this study put emphasis on consideration of types of empowerment in cynicism context. Although types of empowerment can have different implications in different social and organizational contexts, it is important to note that employees and organizational practices are not separate. Therefore, to have comprehensive investigation, managerial activities and employees' positive and negative sources should be considered together in examination of any work outcomes.

\section{Implications for Practice}

This study offers few recommendations for managers and employees. First, it is important not to forget that empowerment is not only something that management gives to employees, but rather a mind-set that employees have about their role in the organization. Therefore, structurally empowered people can manage their perceptions and feel psychologically empowered too. Second, organizational cynicism can be managed by managers. Managers to decrease employees' negative attitudes and to ease cynicism may use empowerment. However, managers should be aware of that simply exhibiting empowering behaviors may not result in the most optimal employee outcomes. Even employees perceive as psychologically empowered, managers also should consider some other individual sources that can buffer or strengthen the cynicism. Particularly for women employees, managers can focus more on psychological and social resources in order to decrease negative work consequences.

Last but not the least, social capital can be developed through formal and informal networks. Managers who develop and organize activities in order to increase social interactions within organizations will enhance positive work outcomes. If employees developed social capital through firm-specific ties and synergistic relationships with managers and colleagues, 
the likelihood of his or her positive attitudes toward organization would be more.

\section{Limitations}

The limitations should be acknowledged in interpreting the results of this study. The first limitation concerns generalization of the tested model. It is important to note that organizational cynicism is a state and can be change over time. Further longitudinal studies would help researchers control for other influential variables over years and test the changes between variables more precisely.

Second, the use of self-reporting method is questionable. Although measurement invariance analysis suggested a good fit with the data and this reduces concerns about common method bias, further studies can use multiple methods and sources to increase the generalizability of the results.

In conclusion, the current study uniquely integrates researches from empowerment, cynicism and social capital literature under the overarching umbrella of many theories (such as empowerment, conservation of research and social role theories). As such, this study may be used as a foundation for scholars interested in theoretically synthesizing and extending empirical research on the interplay of empowerment, cynicism. Further studies may consider other individual-based variables such as psychological capital, social support or other personality characteristics as mediators and moderators. 


\section{REFERENCES}

Anderson, L. (1996). Employee Cynicism: An Examination Using a Contract Violation Framework, Human Relations, 49, 1395-418.

Anderson, J. C., and Gerbing, D. W. (1988). Structural equation modeling in practice: A review and recommended two-step approach, Psychological bulletin, 103, 3, 411.

Ardahan, F. (2012). Sosyal Sermaye Ölçeği geçerlilik, güvenirlilik çalışması. Uluslararası İnsan Bilimleri Dergisi, 9, 2, 773-789.

Avolio, B. J., Zhu, W., Koh, W., and Bhatia, P. (2004). Transformational leadership and organizational commitment: Mediating role of psychological empowerment and moderating role of structural distance. Journal of Organizational Behavior: The International Journal of Industrial, Occupational and Organizational Psychology and Behavior, 25, 8, 951968.

Bashir, S., Nasir, Z. M., Saeed, S., and Ahmed, M. (2011). Breach of psychological contract, perception of politics and organizational cynicism: Evidence from Pakistan. African Journal of Business Management, 5 , 3, 884-888.

Bernerth, J. B., Armenakis, A. A., Feild, H. S., and Walker, H. J. (2007). Justice, cynicism, and commitment: A study of important organizational change variables. The Journal of Applied Behavioral Science, 43, 3, 303326.

Bem, S. L., (1974). The measurement of psychological androgyny. Journal of Consulting and Clinical Psychology, 42, 155-162

Bhatnagar, J. (2007). Predictors of organizational commitment in India: strategic HR roles, organizational learning capability and psychological empowerment. The International Journal of Human Resource Management, 18, 10, pp. 1782-1811.

Bolino, M. C., Turnley, W. H., and Bloodgood, J. M. (2002). Citizenship behavior and the creation of social capital in organizations. Academy of management review, 27, 4, 505-522.

Bommer, W. H., Rich, G. A., and Rubin, R. S. (2005). Changing attitudes about change: Longitudinal effects of transformational leader behavior on employee cynicism about organizational change. Journal of Organizational Behavior: The International Journal of Industrial, Occupational and Organizational Psychology and Behavior, 26, 7, 733-753.
Bourdieu, Pierre . (1980). Le Capital Social: Notes Provisoires. Actes de la Recherche en Sciences Sociales, 3, 2-3.

Brandes, P, Dharwadkar, R. and Dean, J. W., (1999). Does Organizational Cynicism Matter? Employee and Supervisor Perspectives on Work Outcomes. Eastern Academy of Management Proceedings, 150-153.

Brown, M., and Cregan, C. (2008). Organizational change cynicism: The role of employee involvement. Human Resource Management, 47, 4, 667-686.

Byrne, Z. S., and Hochwarter, W. A. (2008). Perceived organizational support and performance: Relationships across levels of organizational cynicism. Journal of Managerial Psychology, 23, 1, 54-72.

Chiaburu, D. S., Peng, A. C., Oh, I. S., Banks, G. C., and Lomeli, L. C. (2013). Antecedents and consequences of employee organizational cynicism: A meta-analysis. Journal of Vocational Behavior, 83, 2, 181-197.

Conger, J. A., and Kanungo, R. N. (1988). The empowerment process: Integrating theory and practice." Academy of management review, 13, 3, pp. 471-482.

Davis, W. D., and Gardner, W. L. (2004). Perceptions of politics and organizational cynicism: An attributional and leader-member exchange perspective. The leadership quarterly, 15, 4, 439-465.

Dean Jr, J. W., Brandes, P., and Dharwadkar, R. (1998). Organizational cynicism. Academy of Management review, 23, 2. 341-352.

Eagly, A. (1987). Sex differences in social behavior: A social role interpretation. Hillsdale, NJ: Erlbaum.

Emmerik, I. H. (2006). Gender differences in the creation of different types of social capital: A multilevel study. Social networks, 28, 1, 24-37.

Feldman, D. C. (2000). The Dilbert syndrome: How employee cynicism about ineffective management is changing the nature of careers in organizations. American Behavioral Scientist, 43, 8, 1286-1300.

Field, A. (2013). Discovering statistics using IBM SPSS statistics. Sage.

FitzGerald, M. R. (2002). Organizational cynicism: Its relationship to perceived organizational injustice and explanatory style. Doctoral dissertation, University of Cincinnati.

Forret, M. L., and Dougherty, T. W. (2001). Correlates of networking behavior for managerial and professional employees. Group \& Organization Management, $26,3,283-311$. 
Gilbert, S., Laschinger, H. K., and Leiter, M. (2010). The mediating effect of burnout on the relationship between structural empowerment and organizational citizenship behaviours. Journal of Nursing Management, 18, 3, 339-348.

Graves, L. M., and Powell, G. N. (1995). The effect of sex similarity on recruiters' evaluations of actual applicants: A test of the similarity-attraction paradigm. Personnel Psychology, 48, 1, 85-98.

Greenglass, E. R., and Julkunen, J. (1989). Construct validity and sex differences in Cook-Medley hostility." Personality and Individual differences, 10, 2, 209-218.

Greve, A., and Salaff, J. W. (2003). Social networks and entrepreneurship." Entrepreneurship theory and practice, 28, 1, 1-22.

Groot, W., Van Den Brink, H. M., and Van Praag, B. (2007). The compensating income variation of social capital." Social indicators research, 82, 2, 189-207.

Hobfoll, S. E. (1989). Conservation of resources: A new attempt at conceptualizing stress. American psychologist, 44, 3, 513.

İş̧̧i, E., Şişman, F. A., and Bektaş, G. (2013). A research on the relationship between personnel empowerment and organizational cynicism." Management, 3, 5, 252-258.

Johnson, J. L., and O'Leary-Kelly, A. M. (2003). The effects of psychological contract breach and organizational cynicism: Not all social exchange violations are created equal." Journal of Organizational Behavior: The International Journal of Industrial, Occupational and Organizational Psychology and Behavior, 24, 5, 627-647.

Kalağan G. (2009). "Araştırma Görevlilerinin Örgütsel Destek Algıları Ile Örgütsel Sinizm Tutumları Arasındaki Iliş̧ki." Unpublished Master Dissertation, Akdeniz University.

Kanter, D. L., and Mirvis, P. H. (1989). The cynical Americans: Living and working in an age of discontent and disillusion. Jossey-Bass.

Karacaoglu, K., and Ince, F. (2012). Reliability and validity of the Turkish version of Brandes, Dharwadkar, and Dean's (1999) organizational cynicism scale: the case of organized industrial zone, Kayseri. Business and Economics Research Journal, 3, 3, 1-77.

Laschinger, H. K. S., Finegan, J., Shamian, J., and Wilk, P. (2001). Impact of structural and psychological empowerment on job strain in nursing work settings: expanding Kanter's model. Journal of nursing Administration, 31, 5, 260-272.
Leana, C. R., and Van Buren, H. J. (1999). Organizational social capital and employment practices. Academy of management review, 24, 3, 538-555.

Lorinkova, N. M., and Perry, S. J. (2017). When is empowerment effective? The role of leader-leader exchange in empowering leadership, cynicism, and time theft. Journal of Management, 43, 5, 1631-1654.

McDonald, S. (2011). What's in the "old boys" network? Accessing social capital in gendered and racialized networks. Social Networks, 33, 4, 317-330.

Nahapiet, J., and Ghoshal, S. (1998). Social Capital, Intellectual Capital, and the Organizational Advantage. Academy of Management Review, 23, 2, 242-266.

O'Neill, B. and Gidengil, E. (Eds.). (2013). Gender and social capital. Routledge.

Orhan, M. (2001). Women business owners in France: The issue of financing discrimination. Journal of Small Business Management, 39, 1, 95-102.

Onyx, J., and Bullen, P. (2000). Measuring social capital in five communities. The journal of applied behavioral science, 36, 1, 23-42.

Polatcan, M., and Titrek, O. (2014). The relationship between leadership behaviors of school principals and their organizational cynicism attitudes. Procedia-Social and Behavioral Sciences, 141, 1291-1303.

Pope, K. S., Butcher, J. N., and Seelen, J. (1993). The MMPI, MMPI-2 \& MMPI-A in court. Washington, DC: American Psychological Association.

Reichers, A. E., Wanous, J. P., and Austin, J. T. (1997). Understanding and managing cynicism about organizational change. Academy of Management Perspectives, 11,1, 48-59.

Spreitzer, G. M. (1995). Psychological empowerment in the workplace: Dimensions, measurement, and validation. Academy of management Journal, 38, 5, 1442-1465.

Subramanian, S. V., Kim, D. J., and Kawachi, I. (2002). Social trust and self-rated health in US communities: a multilevel analysis. Journal of Urban Health, 79, 1, 21-34.

Sürgevil, O., Tolay, E., and Topoyan, M. (2013). Yapisal güçlendirme ve psikolojik güçlendirme ölçeklerinin geçerlilik ve güvenilirlik analizleri. Journal of Yasar University, 8, 31, 5371-5391.

Thomas, K. W., and Velthouse, B. A. (1990). Cognitive elements of empowerment: An "interpretive" model of intrinsic task motivation. Academy of management review, 15, 4, 666-681. 
Wanous, J. P., Reichers, A. E., and Austin, J.T. (2000). Cynicism about organizational change: Measurement, antecedents, and correlates. Group \& Organization Management, 25, 2, 132-153.

Wellington, S., and Spence, B. (2001). Be your own mentor: Strategies from top women on the secrets of success. Random House.

Wilkerson, J. M. (2002). Organizational cynicism and its impact on human resources management. Human resources management: Perspectives, context, functions, and outcomes, 532-546.

Wilkerson, J. M., Evans, W. R., and Davis, W. D. (2008). A test of coworkers' influence on organizational cynicism, badmouthing, and organizational citizenship behavior. Journal of Applied Social Psychology, 38, 9, 2273-2292.

Zimmerman, M. A. (1995). Psychological empowerment: Issues and illustrations. American journal of community psychology, 23, 5, 581-599. 